\title{
Eukaryotic expression, Co-IP and MS identify BMPR-1B protein-protein interaction network
}

\author{
Jianlei Jia ${ }^{1,2}$, Jipeng Jin ${ }^{1,3}$, Qian Chen ${ }^{2}$, Zan Yuan², Haiqin Li ${ }^{2}$ Junhao Bian² and Linsheng Gui ${ }^{1,2^{*}}$
}

\begin{abstract}
Background: BMPR-1B is part of the transforming growth factor $\beta$ super family and plays a pivotal role in ewe litter size. Functional loss of exon-8 mutations in the BMPR-1B gene (namely the FecB gene) can increase both the ewe ovulation rate and litter size.

Results: This study constructed a eukaryotic expression system, prepared a monoclonal antibody, and characterized BMPR-1B/FecB protein-protein interactions (PPIs). Using Co-immunoprecipitation coupled to mass spectrometry (CoIP/MS), 23 proteins were identified that specifically interact with FecB in ovary extracts of ewes. Bioinformatics analysis of selected PPIs demonstrated that FecB associated with several other BMPs, primarily via signal transduction in the ovary. FecB and its associated interaction proteins enriched the reproduction process via BMP2 and BMP4 pathways. Signal transduction was identified via Smads proteins and TGF-beta signaling pathway by analyzing the biological processes and pathways. Moreover, other target proteins (GDF5, GDF9, RhoD, and HSP 10) that interact with FecB and that are related to ovulation and litter size in ewes were identified.
\end{abstract}

Conclusions: In summary, this research identified a novel pathway and insight to explore the PPi network of BMPR-1B.

Keywords: Sheep, BMPR-1B, Co-immunoprecipitation, Mass spectrometry, Protein-protein interaction

\section{Background}

Ovarian folliculogenesis forms the base of ewe ovarian function, and is a key process in the production of mature oocytes during fertilization and hormone release during the estrous cycle [1]. Over the past decade, many studies had showed that ovarian folliculogenesis was regulated by members of TGF- $\beta$ super family such as BMPs, inhibin, and activin [2]. BMPR-1B, a member of BMPs, is a major gene for the ovine ovulation rate, and plays a pivotal role in follicle development and litter size [3]. Previous studies identified that the A746G mutation, a lossof-function mutation in the BMPR-1B gene, generates a protein mutant that promotes steroid production and

\footnotetext{
*Correspondence: 2367542651@qq.com

${ }^{1}$ Key of Laboratory of Plateau Ecology and Agriculture, Qinghai

University, 251\#, Ningda Road, Chengbei District, Xining, Qinghai 810016, China

Full list of author information is available at the end of the article
}

ovulation rate. Consequently, this mutation increased litter size in Australian Merino sheep, and was named the FecB gene (or the FecB mutation of BMPR1B gene) [4]. The FecB gene was also identified as a major gene for litter size in Small Tail Han sheep and Hu sheep [5, 6]. Bone morphogenetic protein receptor $1 \mathrm{~B}$ contains three parts: An N-terminal extracellular ligand binding domain, a single transmembrane region, and a C-terminal serine/ threonine kinase domain [7]. Compared with BMPR$1 \mathrm{~B}$, the mutant protein results in the substitution of the 249th amino acid from glutamine to arginine (Q249R). Consequently, upon binding with BMP ligands, BMPRIIB transphosphorylates the GS domain of the BMPR-1B, which leads to the activation of downstream cascades and the inactivation of the partial receptor [8]. As a result of this, the inhibiting effect of steroidogenesis on GDF5 and BMP4 is weakened, the SMAD state of expression and phosphorylation is changed, the synthesis of estradiol

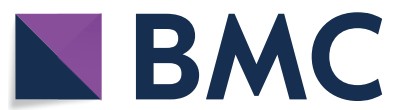

(c) The Author(s) 2020. This article is licensed under a Creative Commons Attribution 4.0 International License, which permits use, sharing, adaptation, distribution and reproduction in any medium or format, as long as you give appropriate credit to the original author(s) and the source, provide a link to the Creative Commons licence, and indicate if changes were made. The images or other third party material in this article are included in the article's Creative Commons licence, unless indicated otherwise in a credit line to the material. If material is not included in the article's Creative Commons licence and your intended use is not permitted by statutory regulation or exceeds the permitted use, you will need to obtain permission directly from the copyright holder. To view a copy of this licence, visit http://creativeco mmons.org/licenses/by/4.0/. The Creative Commons Public Domain Dedication waiver (http://creativecommons.org/publicdomain/ zero/1.0/) applies to the data made available in this article, unless otherwise stated in a credit line to the data. 
by FSH induction is promoted, the synthesis and secretion of progesterone is inhibited, granular cell differentiation of mutation ewes and follicular maturation are accelerated, and ovulation is increased [9]. Although little is known about the follicular regulatory mechanism of BMPR-1B in single, twins, and multiple prolific ewes, these properties of BMPR-1B can provide new concepts for studies of ewe follicular development and litter size.

It has been reported that BMPR-1B exerts additive effects on the ovulation rate, which could be increased by 1.5 to 2.0 for each copy in Booroola Merino sheep [7]. Furthermore, BMPR-1B inhibited granular cells apoptosis, prevented follicular atresia, and promoted ovulation and litter size. This may be an important physiological mechanism with which BMPR1B affects fecundity in sheep [8]. Miao compared the ovarian proteomes of Han ++ and Han BB ewes have indicated that Han BB ewes higher ovulation rate may relate to mitochondrial oxidation functions protein expressions, and it could provide a prospective understanding of the molecular mechanism for high prolificacy of Small Tail Han sheep [10]. The development of post-genomics, proteomics, transcriptomics, metabolomics, and bioinformatics offers unprecedented advantages for research on the biological function of genes and underlying biological molecular regulatory mechanisms. This study applied eukaryotic expression, Co-IP, and MS to BMPR-1B, a signal transduction protein found in intracellular and extracellular signal transduction pathway in Smads, p38-MAPK, and Erk-MAP.

To explore the biological functions of BMPR-1B and its resulting protein in ewe folliculogenesis, a eukaryotic expression vector of pcDNA3.1a-BMPR-1B was constructed for the highly efficient expression of BMPR-1B protein in SF9. Furthermore, a monoclonal antibody was prepared and a CoIP-MS approach was used to identify BMPR-1B protein-protein interactions (PPIs). In addition, the signal pathway of target proteins was analyzed and bioinformatics prediction indicated that BMPR-1B interacted with proteins that promoted ovulation in ewe ovary. CoIP-MS identified 23 BMPR-1B proteins with significant correlation, including PPIs with many Smads. These results associated BMPR-1B with reproduction processes and signal pathways. The target proteins were primarily related to developmental processes, multicellular organismal processes, and biological regulation. The result also showed that BMPR-1B interacted with several binding proteins, such as BMP2, BMP4, GDF5, GDF9, RhoD, and HSP 10. The Co-IP/MS results were further assessed by western blotting. In summary, these results indicated a new concept of BMPR-1B PPIs and their biological functions for sheep litter size. Furthermore, this study laid a technical foundation for the in vitro expression of sheep BMPR-1B. For the further study of the biological function and specificity of developed diagnostic reagents, BMPR-1B was identified the major gene for sheep.

\section{Materials and methods}

Experimental ewes with clear lambing record were killed by bloodletting via the carotid artery. The ovaries of Small Tailed Han sheep were collected from a slaughter house in accordance with approved guidelines, and ovary samples were peeled and washed to remove all surface fat and ligaments. The ovaries were then transferred to sterile plastic tubes and stored at $-80^{\circ} \mathrm{C}$.

\section{Detection of FecB mutations}

A primer pair was designed to detect single nucleotide polymorphisms in exon8 of the BMPR-1B gene in blood samples of ewes. The procedure used PCR-RFLP and followed the description of Wang [11]. The primer sequences were as follows: F: 5'-GTCGCTATGGGGAAG TTTGGATG-3', R: 5'-CAAGATGTTTTCATGCCTCAT CAACACGGTC- $3^{\prime}$.

\section{Gene cloning}

$\mathrm{BB}$ and ++ genotype ewes were selected, and the total RNA of their ovaries was extracted using an RNA extraction kit (TaKaRa, China). After the RNA was reverse transcribed to cDNA, it was amplified in a volume of $25 \mu \mathrm{l}$. Amplification was performed for 35 cycles using DNA thermal cycler (Bio-Rad, USA). The first cycle was at $94{ }^{\circ} \mathrm{C}$ for 2 min followed by 35 subsequent cycles of $94{ }^{\circ} \mathrm{C}$ for $30 \mathrm{~s}, 59.5^{\circ} \mathrm{C}$ for $30 \mathrm{~s}$, then $72{ }^{\circ} \mathrm{C}$ for $60 \mathrm{~s}$, and the last cycle at $72{ }^{\circ} \mathrm{C}$ for $7 \mathrm{~min}$.

The PCR products were isolated from the agarose gel with a MiniBEST Agarose Gel DNA Extraction Kit (TaKaRa, China). $5 \mu \mathrm{L}$ of purified PCR products (BMPR$1 \mathrm{~B} / \mathrm{FecB}$ ) were ligated into $0.5 \mu \mathrm{L}$ of pMD19-T with 5.5 $\mu \mathrm{L}$ Solution I using T4 DNA ligase at $4{ }^{\circ} \mathrm{C}$ overnight. $10 \mu \mathrm{L}$ of transformed ligation mixture was inserted into $100 \mu \mathrm{L}$ of Escherichia coli DH5a in LB agar containing $\mathrm{X}$-gal, IPTG, and Ampicillin. This ligation mixture was transformed into $E$. coli DH5a using an ice-water bath for $30 \mathrm{~min}$ and heat shock at $42{ }^{\circ} \mathrm{C}$ for $45 \mathrm{~s}$, followed by incubation on ice for $1 \mathrm{~min}$. The transformation products were cultured on LB agar overnight. Positive clones were sequenced by Sangon Biotech (China).

\section{Eukaryotic expression recombined target gene}

pcDNA3.1a (eukaryotic expression plasmid vector) and pMD19-T-BMPR-1B/FecB (cloning vector) were digested with BamH I and Xho I (TaKaRa, China) at $37{ }^{\circ} \mathrm{C}$ for $4 \mathrm{~h}$. The digested products were identified by $2 \%$ agarose gel electrophoresis. The empty vector and objective gene 
fragment were recovered from agarose, using a gel extraction kit (TaKaRa, China). The empty vector was ligated into the objective gene fragment using T4 DNA ligase (TaKaRa, China) at $16^{\circ} \mathrm{C}$ overnight. Ligation products were cultured in LB agar containing ampicillin at $37^{\circ} \mathrm{C}$ overnight. Positive clones were sequenced by Sangon Biotech (China).

Protein expression of each gene was assessed using a $10 \mathrm{ml}$ suspension culture of Spodoptera frugiperda (SF9) cells (Invitrogen, USA). In a $2.0 \mathrm{ml}$ tube, $25 \mu \mathrm{L}$ of plasmid DNA $(25 \mu \mathrm{g})$ was diluted in $10 \%$ fetal calf serum Grace's medium (Invitrogen, USA). $150 \mu \mathrm{L}$ of cell transfection reagent (QIAGEN, Germany) was diluted in $1.5 \mathrm{ml}$ of the same medium in a $2.0 \mathrm{ml}$ tube. The diluted plasmid DNA was then added dropwise to the diluted cell transfection reagent and the mixture was gently blended to avoid precipitation, and then left at room temperature for $20 \mathrm{~min}$. Finally, the entire mixture was added to the cells and incubated at $70 \mathrm{rpm}$ on a shaking table at $28{ }^{\circ} \mathrm{C}$ until the cytopathic effect (CPE) exceeded 80\% (72-96 h. The transformed cells and total cells were counted with inverted microscope, respectively. 5-7 microscopic fields were randomly selected in $400 \times$ lens, and more than 700 total cells were counted. The average transfection rate: Transfection rate $=$ the number of transformed cells/total cells $\times 100 \%$ ). Then, supernatants and precipitation were separately collected, and proteins were separated by SDS-PAGE. The recombinant protein was purified using the Ni-NTA Superflow Protein Purification Kit (QIAGEN, Germany).

\section{Generation of anti-BMPR-1B and anti-FecB monoclonal antibodies}

MAbs production was conducted by GenScript (USA). $\mathrm{BAL} \mathrm{b} / \mathrm{c}$ mice were immunized with the above-described purified BMPR-1B/FecB proteins and the production of specific hybridomas was performed following standard protocols. Clones 3M2/R1, 2D8/F1, and 1G6/H4 were selected as hybridomas for this study. They were produced anti-BMPR-1B antibodies, clones 8G2/T3, 4F7/ G6, and $1 \mathrm{M0} / \mathrm{H} 10$, which produced anti-FecB antibodies. 3A10/B8 that produced control antibodies.

\section{Identification of the BMPR-1B/FecB interacting proteins in the ovary of ewes}

Each Co-immunoprecipitation (Co-IP) was conducted three times. For Co-IP, the BMPR-1B/FecB and interacting proteins in ewes' ovary were enriched using the Mag sProtein A/G Co-Immunoprecipitation Kit (BioCanal, China). For regular Co-IP, $0.1 \mathrm{~g}$ extracts from the ovaries of ewes were lysed with $1 \mathrm{ml}$ lysis buffer at $4{ }^{\circ} \mathrm{C}$ for $30 \mathrm{~min}$ and sonicated in a water bath sonicator at amplitudes of $22 \%$ for $60 \mathrm{~s}(0.1 \mathrm{~s}$ on and $1 \mathrm{~s}$ off) [12]. $5 \mathrm{mg}$ of total protein was used for immunoprecipitation with $100 \mu \mathrm{g}$ of IgA.
The $\mathrm{BMPR}-\mathrm{B} / \mathrm{FecB}$ and interacting proteins were coimmunoprecipitated from whole ewe ovary extracts via Mag sProtein A/G Immunoprecipitation Kit and regular Co-IP. The empty vector, which was expressed by SF9 cells, served as negative control. The immunoblot results indicated that the interacting proteins of BMPR- $1 \mathrm{~B} / \mathrm{FecB}$ were enriched in the pulldown. In contrast, BMPR-B/ $\mathrm{Fec} B$ and interacting proteins were not identified in the control vector pulldown. This demonstrated that the method was efficient, specifically co-immunoprecipitated $\mathrm{BMPR}-\mathrm{B} / \mathrm{FecB}$, and interacted with proteins from the ovary extracts of ewes.

\section{Protein identification and bioinformatics analyses}

LC-MS analysis was conducted by Applied Protein Technology (Shanghai, China). 5800 MALDI-TOF/TOF (AB Sciex, USA) was used for mass spectrometer (MS) data analyses. For quantitative analysis, a protein must have at minimum one unique peptide match with the MS ratios. $A \geq 3.0$ or $\leq 3.0$-fold cutoff value was used to identify up-regulated and down-regulated proteins with a $p$ value $<0.05$.

Functional annotation and classification of all identified proteins were determined by using the Blast2GO program against the uniprot database. Pathway analyses were extracted using the search pathway tool of the KEGG mapper platform (http://www.genome.jp/kegg/ mapper.html). Pathway enrichment statistics were conducted by Fisher's exact test, and the pathways with a corrected $p$ value $<0.05$ were defined as the most significant pathways. The search tool for the retrieval of interacting genes/proteins database for the prediction of the physical and functional interactions was used to analyze the PPI network. The graphical visualization and analysis of interaction network was performed in GeneMANIA software.

\section{Results}

Detection of polymorphism in the BMPR-1B (FecB) gene

DNA was extracted from the whole blood of ewes using a DNA preparation kit (TaKaRa, China). The concentration and purity of the extracted genomic DNA were determined by spectrophotometer (Germany). The PCR product was about $140 \mathrm{bp}$, located on exon 8 of the BMPR-1B gene. The FecB mutations could be identified via RFLP method using Restriction Endonuclease Ava II. The PCR product of exon 8 of the BMPR-1B gene can generate two alleles by Ava II digestion: the wild-type allele $(+)$ and the mutant allele (B). The wild-type allele $(+)$ was not sensitive to Ava II and could not be cut, while the mutant allele (B) was cut by Ava II, which yielded two DNA fragments of 110 and $30 \mathrm{bp}$. Analysis showed that the A746G of 


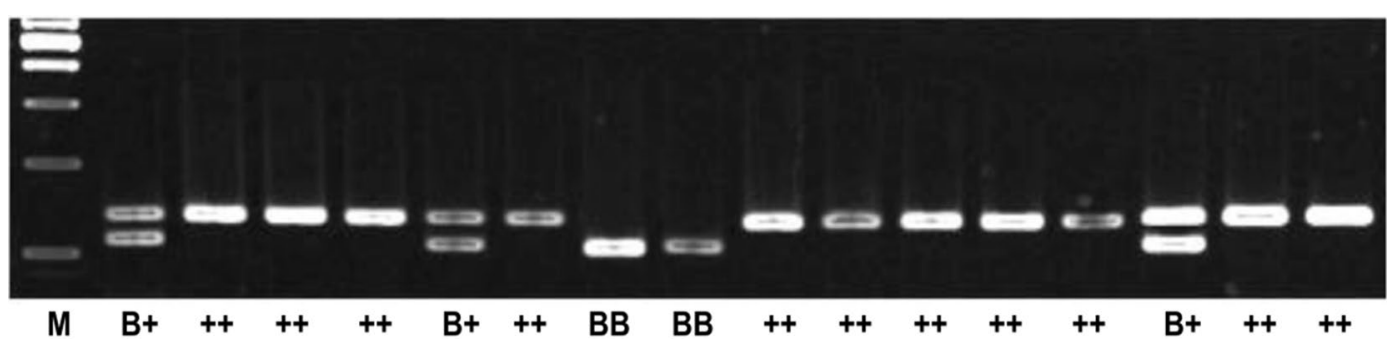

Fig. 1 The FecB mutation of BMPR-1B gene was digested by Avall

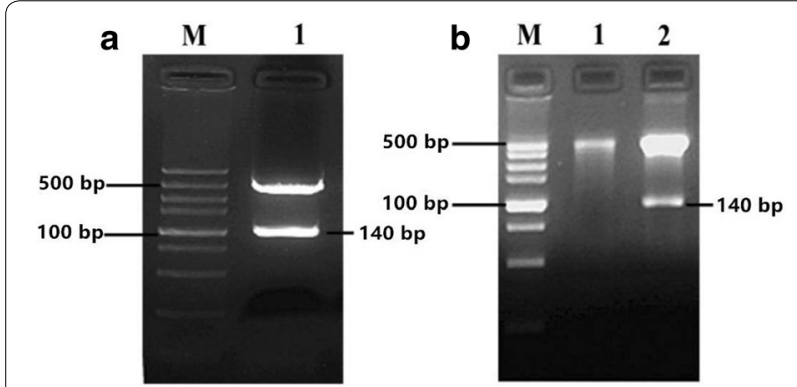

Fig. 2 Agarose electrophoresis of isolated plasmid at native condition (a) and at digested with BamH I and Xho I enzymes (b). a M was DNA marker, 1 was recombinant plasmid. b 1 was empty plasmid, 2 was recombinant plasmid

BMPR-1B gene could sensitize it to Ava II, and the sequence $(\mathrm{G} \mid \mathrm{GACC})$ of $\mathrm{FecB}$ mutation was recognized as the site of cutting (Fig. 1).

\section{Eukaryotic expression recombined gene BMPR-1B} and FecB

Agarose electrophoresis identified two bands in the pMD19-T-BMPR-1B/FecB plasmid and only one band in the pMD19-T-NP plasmid. Figure 2 confirmed that there was a $140 \mathrm{bp}$ band (DNA fragment) by cleavage of pcDNA3.1a-BMPR-1B/FecB plasmid by plasmid digestion of BamH I and Xho I restriction endonuclease. However, for the pMD19-T-NP, the target 140 bp band (DNA fragment) did not appear.

\section{Generation of anti BMPR-1B and anti FecB monoclonal antibodies}

After transfection, SF9 cells were monitored for CPE by inverted microscope. And the pcDNA3.1a-BMPR$1 \mathrm{~B} / \mathrm{FecB}$ transfected group showed the CPE of visible to naked eye compared with controls $24 \mathrm{~h}$ later (Fig. 3). After 7 days of monitoring, the result indicated a CPE expression of $80 \%$ between 72 and 96 h post-transfection.

The supernatants and precipitate were analyzed by SDS-PAGE in an $8 \%$ polyacrylamide gel, and coomassie brilliant blue R-250 staining was used to visualize target proteins. The recombinant proteins were mainly identified via precipitation (Fig. 4a), and the Ni-NTA Superflow Protein Purification Kit (Fig. 4b) was used to purify recombinant proteins. Figure $4 \mathrm{c}$ shows that the specific hybridomas and monoclonal antibody were produced by standard protocols via BAL b/c rats, using the purified proteins described above. The ELISA method was

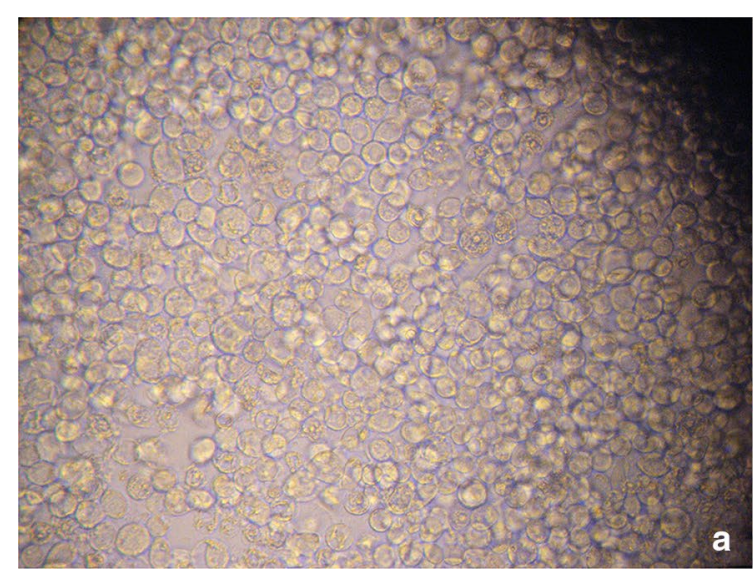

Fig. 3 Sf9 of post-transfection (a) and Sf9 of Normal (b)

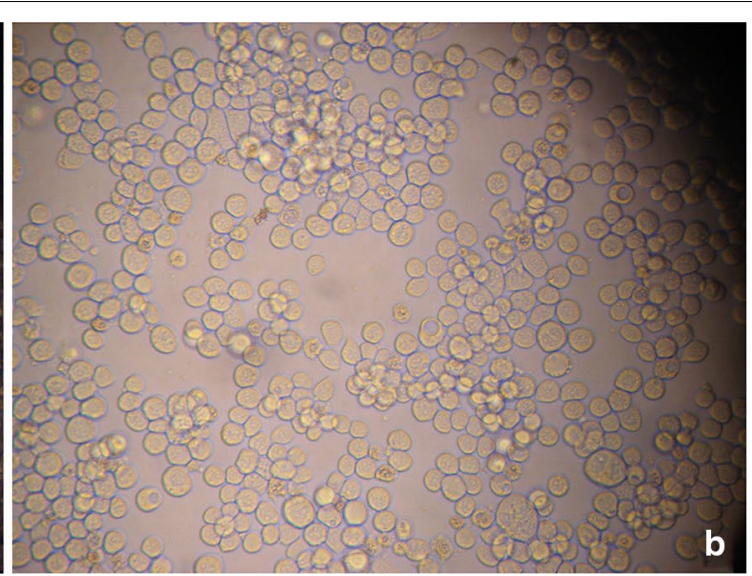




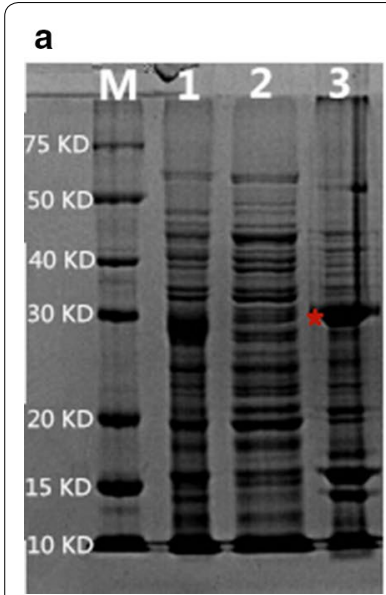

b

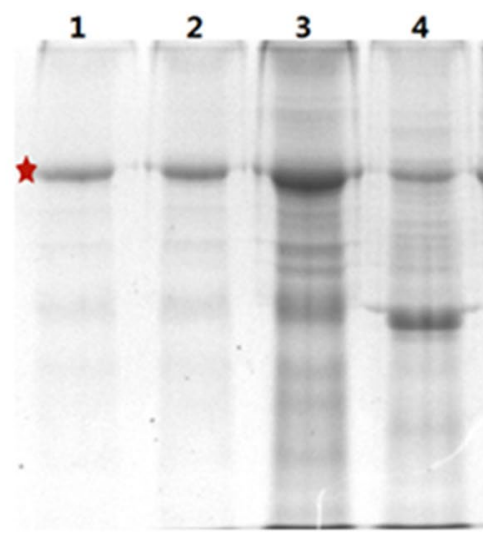

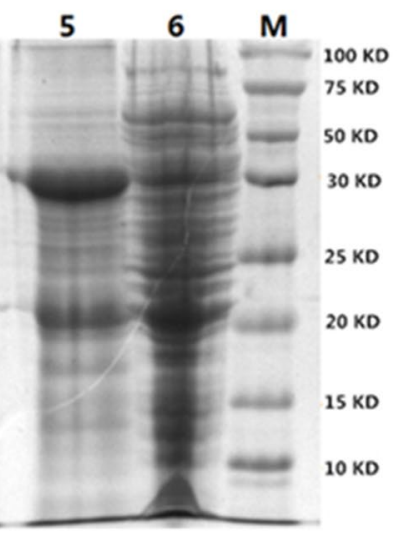

C

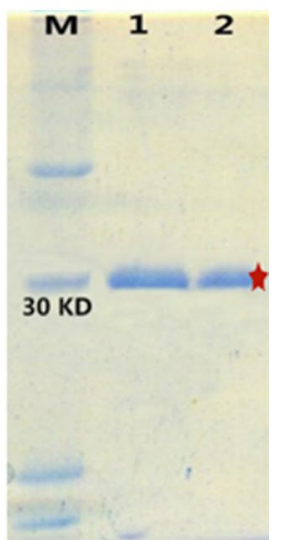

Fig. 4 a SDS-PAGE of Protein extraction M was Marker; 1 was SDS-PAGE of total protein; 2 was SDS-PAGE of supernatant; 3 was SDS-PAGE of precipitation. b Purification of BMPR-1B recombined protein M. Protein marker; 1-3. Purified recombined protein; 4. Flow through; 5. Unpurified inclusion bodies; 6 . The total protein before induction. c Western blotting of antibody

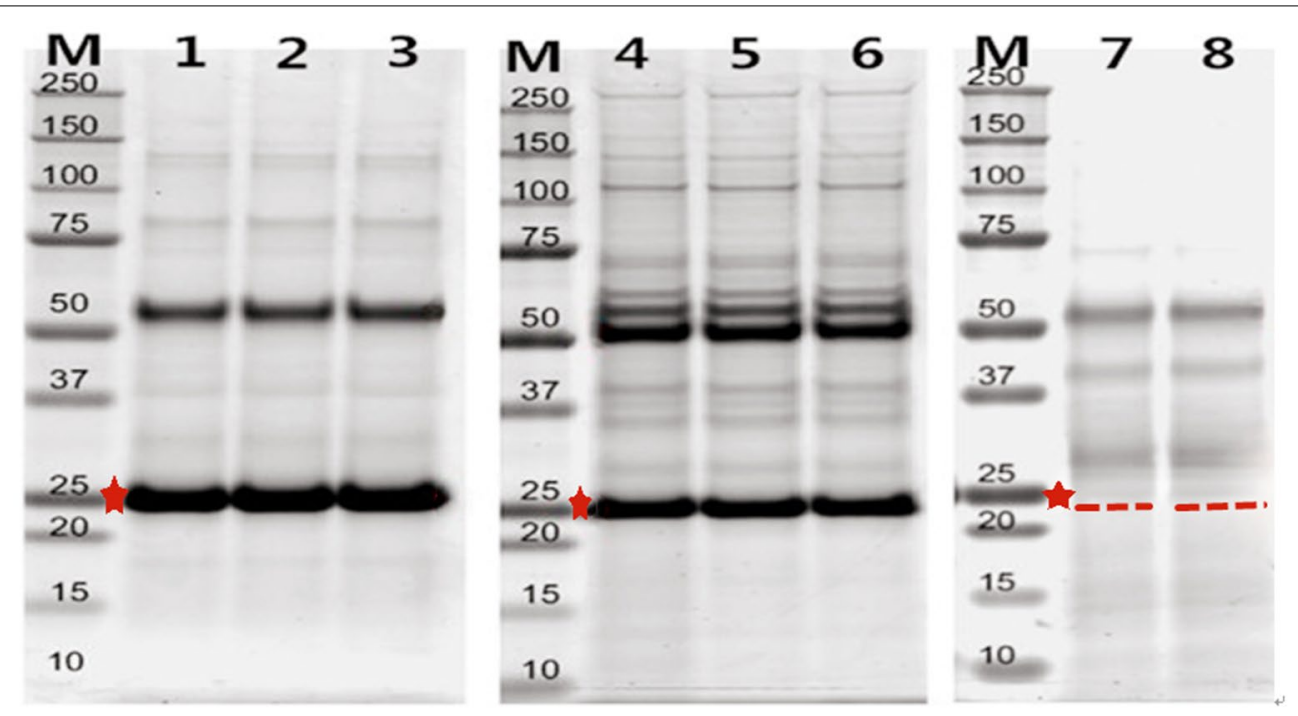

Fig. 5 Identification of BMPR-1B/FecB interacting proteins

used to detect the BMPR-1B/FecB antibody titer, and the serum antibody titer was measured when positive/negative $(\mathrm{P} / \mathrm{N})$ exceeded or was equal to 2.1 on OD $450 \mathrm{~nm}$. The results showed that the high-titer rat anti-BMPR-1B/ FecB serum had been prepared by four immunizations. Then, the monoclonal antibodies were typed by ClonaCell Kit (StemCell, Canada).

\section{Identification of the BMPR-1B interacting proteins in ovary extracts of ewes}

The BMPR-1B/FecB interacting proteins were efficiently and specifically screened from ovary extracts of ewes via SDS-PAGE (Fig. 5). Coomassie staining gels showed that several bands only appeared in Co-IP of BMPR-1B (samples 1, 2, and 3) and Co-IP of FecB (samples 4, 5, and 6), but were not present in the control vector (samples 7 and 8).

Sixty-three immunoprecipitated proteins were successfully identified with Ovis aries or Bos taurus database matching in Mascot. Then, the most likely associations between these target proteins and BMPR$1 \mathrm{~B} / \mathrm{FecB}$ were computed by the manual thresholding approach and a probabilistic PPI prediction algorithm, which identified 34 high-confidence candidates. Table 1 is our 24 of these 34 proteins were at least threefold more abundant between CoIP of BMPR-1B and $\mathrm{Fec} B$ groups. BMPR-1B protein and 23 target CoIP 
proteins, and Table 1 is in identification of the BMPR$1 \mathrm{~B}$ interacting proteins in ovary extracts of ewes part of paper result.

\section{Validation of selected BMPR-1B/FecB PPIs}

Previously research showed that as the natural ligand of BMPR-1B, GDF5 and BMP4 participated in the ewe ovarian folliculogenesis. Both proteins were detected in the current Co-IP/MS study. Furthermore, specific interactions of several identified candidate proteins with BMPR-1B/FecB were identified by CoIP, followed by immunoblot: BMP2, GDF9, RhoD, and HSP 10 (Fig. 6). All these candidate proteins were identified by Western blotting (positive and negative validation, see Fig. 7). In summary, the PPIs prediction results confirmed the specific interactions of target proteins with $\mathrm{BMPR}-1 \mathrm{~B} / \mathrm{FecB}$, further providing evidence of the validity for the Co-IP/MS approach.

\section{Gene ontology and pathway analysis}

To explore biological processes associated with FecBinteracting proteins, enrichment analysis in the Gene Ontology (GO) domain "Biological Process" was

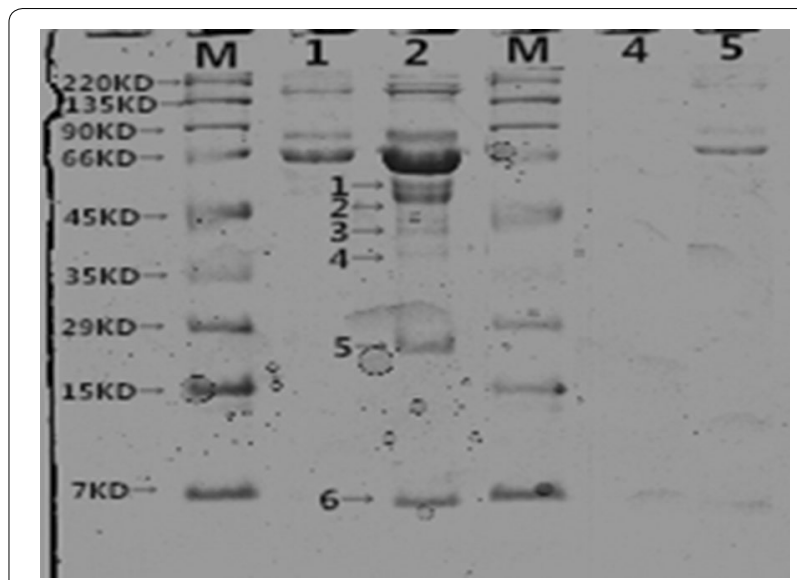

Fig. 6 SDS-PAGE of BMPR-1B interacting proteins of ewes' ovary extracts by ColP Lanes: M was Marker; 1 was control group; 2 was experimental group; 3 was supernatant of antibody for ColP; 4 was NP control; 5 was supernatant of antigen for ColP. Bands: 1 was BMP4; 2 was RhoD; 3 was GDF9; 4 was BMP2; 5 was HSP 10; 6 was DGF5

performed (Fig. 8). The results identified two predominant themes: binding and signaling. For the signaling term, the pivotal term in ewe ovarian folliculogenesis mainly

Table 1 Merged list of identified BMPR-1B interacting proteins from ColP and MS

\begin{tabular}{|c|c|c|c|c|c|}
\hline Sample & Protein name & No. NCBI & Data sources & Molecular weight & $\mathrm{PI}$ \\
\hline 1 & BMPR-1B & gi|57164243 & Ovis aries & 32018.6 & 6.67 \\
\hline 2 & SOD[Cu-Zn]-like & gi|426237454 & Ovis aries & 15856 & 6.14 \\
\hline 3 & Transgelin & gi|426244582 & Ovis aries & 25598.9 & 9.06 \\
\hline 4 & MTHFR & gi|281833111 & Bos taurus & 15517.9 & 3.9 \\
\hline 5 & Histone $\mathrm{H} 3$ & gi|426250704 & Ovis aries & 15536.5 & 11.24 \\
\hline 6 & GDF9 & gi|402244329 & Ovis aries & 19644.6 & 4.76 \\
\hline 7 & Calmodulin & gi|262073073 & Bos taurus & 16703.3 & 4.1 \\
\hline 8 & Aldose reductase & gi|426228047 & Ovis aries & 36291.6 & 5.95 \\
\hline 9 & Hemoglobin subunit mu & gi|139947644 & Bos taurus & 16120.3 & 6.75 \\
\hline 10 & Alpha globin chain & gi|1789 & Ovis aries & 15283.9 & 7.94 \\
\hline 11 & MRCL3 & gi|223633898 & Ovis aries & 19851.5 & 4.72 \\
\hline 12 & Myosin light chain 6 & gi|165875535 & Ovis aries & 16094.8 & 4.6 \\
\hline 13 & Galectin-1 & gi|47779226 & Ovis aries & 15150.4 & 5.02 \\
\hline 14 & Annexin A2 & gi|147899370 & Ovis aries & 38872.9 & 6.92 \\
\hline 15 & Glyceraldehyde-3-phosphate dehydrogenase & gi|296785215 & Ovis aries & 36110.4 & 8.51 \\
\hline 16 & Glutathione S-transferase Mu & gi|426216178 & Ovis aries & 21331.9 & 8.42 \\
\hline 17 & PEBP & gi|426224189 & Ovis aries & 21082.7 & 6.51 \\
\hline 18 & Nitric oxide-inducible gene protein & gi|426252227 & Ovis aries & 112526 & 7.03 \\
\hline 19 & Beta-A globin chain & gi|86129749 & Ovis aries & 16050.3 & 6.49 \\
\hline 20 & BMP2 & gi|353681895 & Ovis aries & 11258.92 & 9.96 \\
\hline 21 & BMP4 & gi|160333315 & Ovis aries & 46611.90 & 8.57 \\
\hline 22 & GDF5 & gi|196119889 & Ovis aries & 7456.80 & 10.01 \\
\hline 23 & RhoD & gi|803191482 & Bos taurus & 21927.32 & 8.76 \\
\hline 24 & HSP 10 & gi|27805927 & Bos taurus & 10931.69 & 8.89 \\
\hline
\end{tabular}




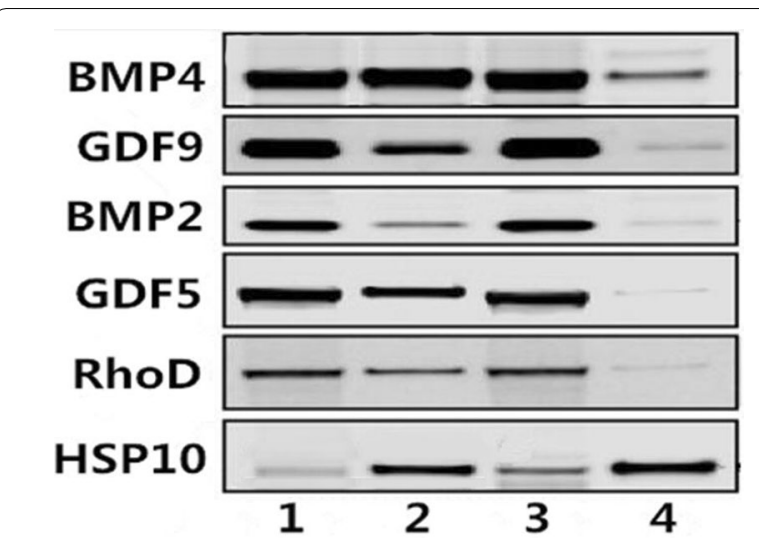

Fig. 7 Western blotting of BMPR-1B/FecB interacting proteins. The pulldown of interacting proteins were immunobloted with BMPR-1B/ FecB antibodies. The same pulldown were also immunobloted with BMP 4, GDF9, BMP2, GDF5, RhoD and HSP10 antibodies. 1 was verification of BMPR-1B antibodies, 2 was verification of $\mathrm{FecB}$ antibodies, 3 was verification of target interacting proteins antibodies related to signal transduction (e.g., "TGF-beta signaling pathway" and "Cytokine-cytokine receptor interaction"). Other developmental process terms included "Biological regulation", "Cellular process", "Growth", and "Metabolic process". The terms unrelated to these phenomena and unconnected to any nodes included "Detoxification" and "Immune system process".

To provide further insight into the biological processes identified by this approach, Fishers' test (significance A/B Test) was applied to target terms (Fig. 9). Terms with the highest number of associated proteins from these results were the proteins that resulted in the identification of an enriched biological process. For example, the identification of the "Signaling" and "Reproduction" terms were in large part the result of the large number of TGF- $\beta$ family proteins in the list of BMPR-1B-interacting proteins. In contrast, the enrichment for "Regulation of translation" resulted from the presence of initiation and elongation factors (e.g., BMP2 and BMP4) in the list of BMPR-1B/ FecB-interacting proteins.

The major pathways associated with FecB-interacting proteins were identified using KEGG Pathway Analysis via KAAS software. Twenty-eight of total of 103

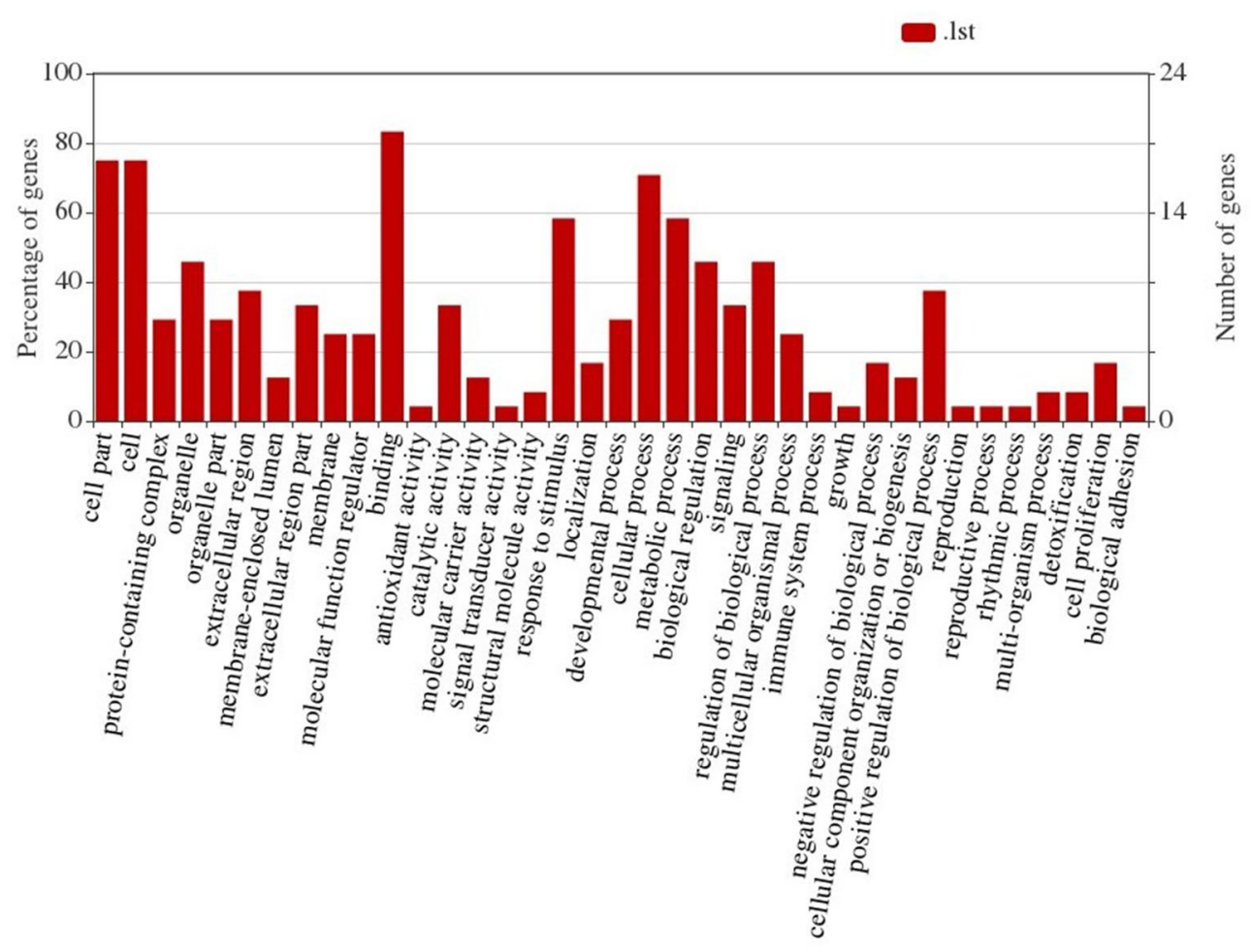




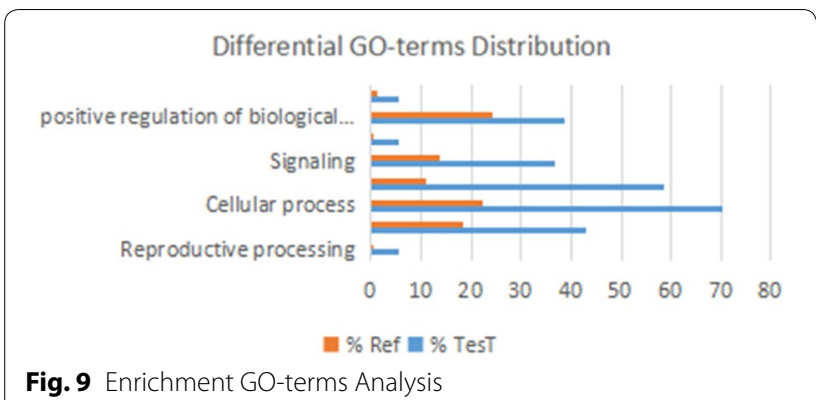

pathways were significantly enriched $(\mathrm{p}<0.05)$. The significantly enriched pathways were "TGF-beta signaling pathway", "Ovarian steroidogenesis pathway", "MAPK signaling pathway", "Cytokine-cytokine receptor interaction", "Hippo signaling pathway", and "Signaling pathways regulating pluripotency of stem cells" (Fig. 10a, b). The results of KEGG pathway analysis matched the results of gene ontology analysis.

\section{Protein-Protein interaction pathway prediction analyses}

To explore the information of the FecB-interaction network, connected proteins among the 24 proteins were analyzed via GeneMANIA software and Uniport database. As reported, BMPR-1B, BMP2, BMP4, GDF5, GDF9, and HSP10 constituted a complex and strong PPI network (Fig. 11). Moreover, interestingly, the target proteins displayed different mutual interections with other pathways in the complex PPI network between coexpression and pathway (Fig. 12). Therefore, based on these experimental results, an BMPR-1B/FecB pathway that could regulate sheep oocyte development and ovulation (Fig. 13) was designed. The predicted pathway corroborated the importance of pathways related to signal transduction for ewe oocyte development and ovulation.

\section{Discussion}

Gonadotropins, such as follicle stimulating hormone (FSH) and luteinizing hormone (LH), are usually considered to regulate ewe ovarian oocytes maturity and ovulation. Research confirmed that various intra-ovarian factors, including BMPR-1B, could control the release of these gonadotropin hormones (FSH and LH) [13]. A recent study showed that the BMPR $1 \mathrm{~B} / \mathrm{FecB}$ gene was widely expressed in ovary tissues such as granulocytes, oocytes, follicles, and corpus luteum [14]. Miao et al. explored the mechanisms for sheep fecundity on protein level, they found $\mathrm{FecB}$ mutation ewes had a lower expression level in ribosome related protein, Bioinformatics analysis showed that Oxidative phosphorylation occurred in $10.07 \%$ different expression proteions of FecB mutation ewes, and these different expression proteions of FecB mutation ewes were all lower than in Non-FecB mutation ewes in mTOR signaling pathway, including ERK1/2, eIF4B and S6 [10]. However, it was not reported that BMPR-1B protein was expressed in vitro, then researched the regulatory pathways of BMPR-1B protein and its interaction molecules (signals) by bioinformatics technology. This research could help to get a deep understanding of sheep prolificacy.

FecB PPIs were identified via the Co-IP/MS method, and the target signal process was screened to better understand the biological pathway of the FecB-interaction protein associated signal transduction functions in ovary extracts of ewes. Sixty-three proteins were successfully identified via Ovis aries or Bos taurus database matching in Mascot. The most likely associations between these target proteins and BMPR- $1 \mathrm{~B} / \mathrm{FecB}$ were computed by the manual thresholding approach and a probabilistic PPI prediction algorithm. Thirty-four high-confidence candidates were identified, 24 of which were at least threefold more abundant between Co-IP of BMPR-1B and FecB groups. TGF- $\beta$ was identified as the most prominent protein family, including the number of Smads proteins and active proteins. The results identified enrichment for signaling processing via Smads and reproductive processing functions via BMP proteins. In summary, this study provided new insights into PPIs, biological functions, and the roles of the FecB protein.

Proteins are synthesized in ribosomes and transferred to specific organelles to participate in the normal activities of the organism [15]. As a transmembrane protein, BMPR-1B mediates the signal transduction between intracellular and extracellular lumen by participating in life activities and material exchange [16]. GDF5 and BMP4 have been confirmed to be the natural ligands of BMPR-1B, which directly act on secretion of progesterone in ewe granule cells $[17,18]$. BMP2 and GDF9 inhibited the release of cAMP and regulated both the synthesis and secretion of progesterone, estradiol, and androstenedione thus affecting ewe ovarian folliculogenesis and litter size $[19,20]$. RhoD indirectly affects ewe ovarian folliculogenesis and litter size by participating in the MAPK signaling pathway and in various cellular processes. HSP10 either directly or indirectly participates in cell proliferation apoptosis, inflammatory immune response, and reproductive processes [21, 22].

As a result of the interaction between pituitary gonadotrophins, autocrine, and paracrine factors of the BMP family, immature oocytes are transformed to fully grown oocytes. This presents the meiotic maturation of an oocyte in the pre-ovulary follicles toward fertilization just before ovulation [23]. BMPs participate in multiple cellular activities such as proliferation, cellular differentiation, migration, organization, and apoptosis [24]. BMPR-1B is the major gene of ewe litter size for many 


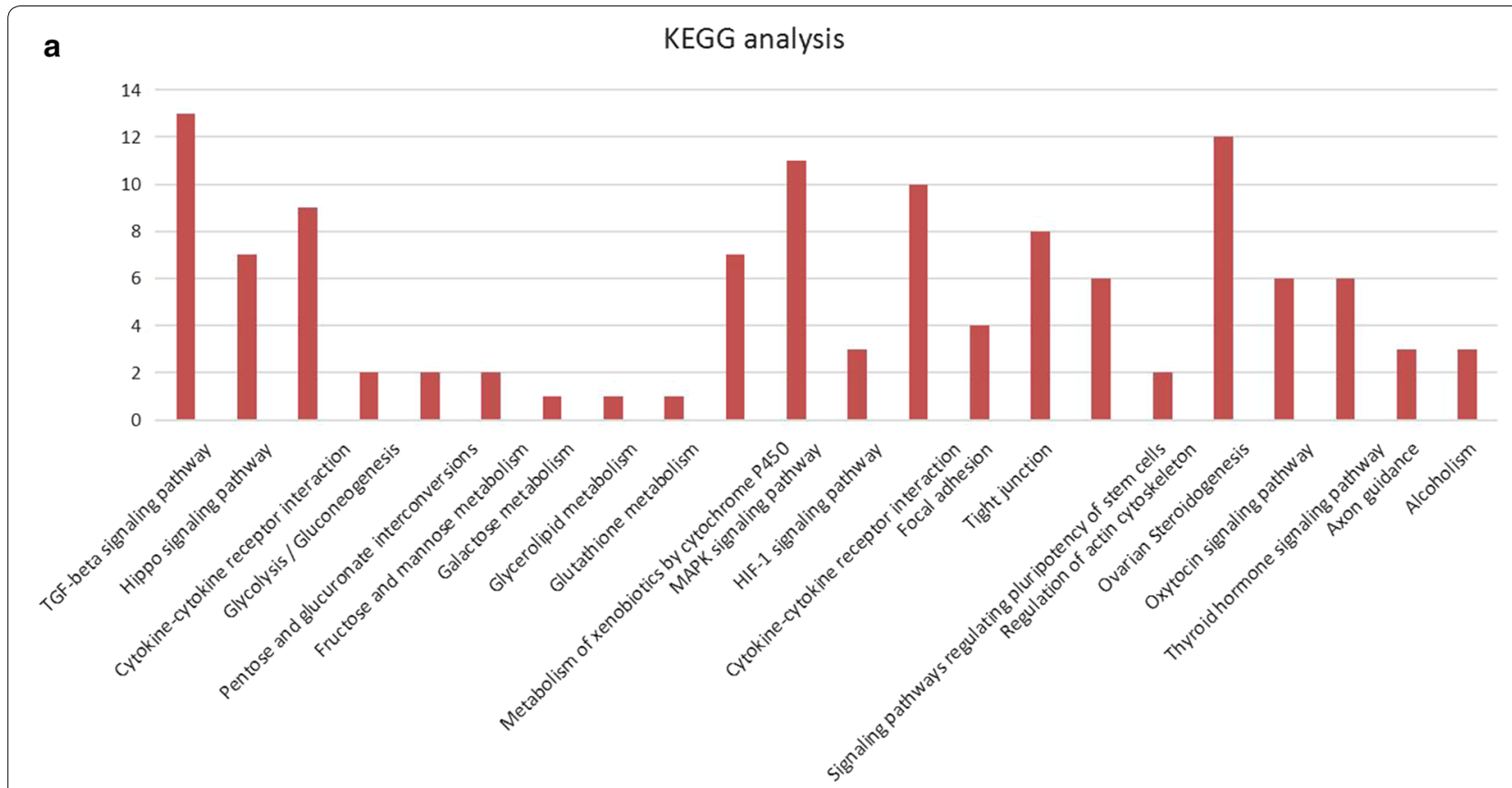

b

Enriched KEGG

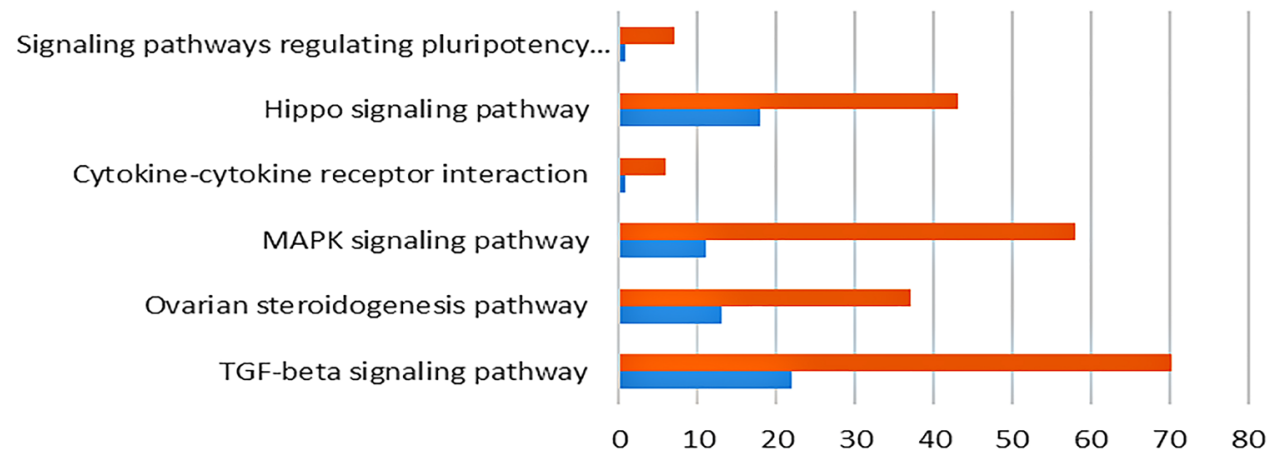

$\square \%$ Test $\quad$ a Ref

Fig. 10 a FecB-interacting proteins KEGG pathway. b Enrichment KEGG pathways analysis. Fisher's Exact Test, $P$ value $<0.01$

sheep breeds, and regulates ewe ovarian oocytes maturation and ovulation to control litter size by the Smads pathway in interaction with the BMP signaling pathway [25]. The Smads pathway is very important in regulating the maturation and ovulation of ewe ovarian oocytes, and cross interacted with other pathways, such as the MAPK signaling pathway, the Cytokine-cytokine receptor interaction pathway, the TGF- $\beta$ signaling pathway, the Hippo signaling pathway, and the Canonical Wnt/ $\beta$ catenin pathway [26]. The results of GO, KEGG, and PPi showed that target proteins were enriched during the developmental process, multicellular organismal process, pigmentation, cellular process, biological regulation,
TGF-beta signaling pathway, Hippo signaling pathway, and Cytokine-cytokine receptor interaction.

Therefore, according to recent studies and the results presented here target proteins could be concluded to be mainly regulated by the intracellular signal transduction pathway (Smads pathway and p38-MAPK pathway) and the extracellular signal transduction pathway (Erk-MAP pathway). The initial recruitment of primordial follicles is, in fact, independent of gonadotropin hormones and is likely controlled by various intra-ovarian paracrine/autocrine factors, one of which is BMPR1B. When paracrine/autocrine factors bind to the BMP receptor, the type II receptor transphosphorylates 


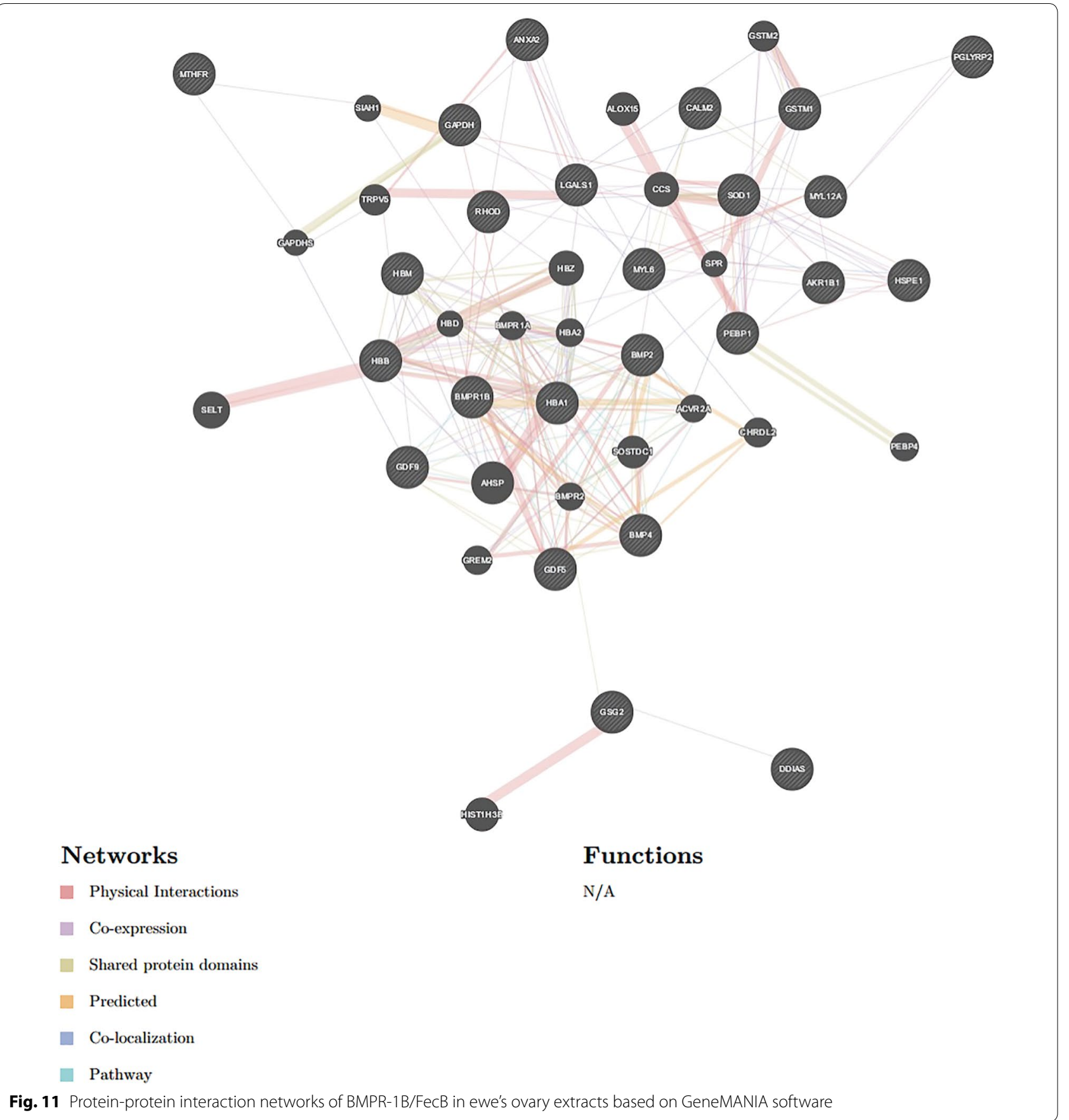

the type I receptor at an intracellular juxtamembrane site that is rich in glycine and serine residues (the GS domain). Consequently, the type I receptor transphosphorylates the R-Smads signaling proteins Smad 1, 2, 3, 5 , and 8 . These activated R-Smad proteins bind together in multiple protein complexes with Smad 4 (which is also named the common mediator Smad or Co-Smad) $[27,28]$. The R-Smad-Co-Smad complex then moves to the nucleus. Inside the nucleus, these complexes then bind to specific areas of DNA and collaborate with particular transcription factors. Thus, they regulate the activity of target genes, activate transcription of downstream BMP4 and GDF5 genes, and regulate follicular development and ovulation [29-31]. Hence, the major determinant of Smad signaling depends on the specificity to binding to type-I receptors. With the synergism 


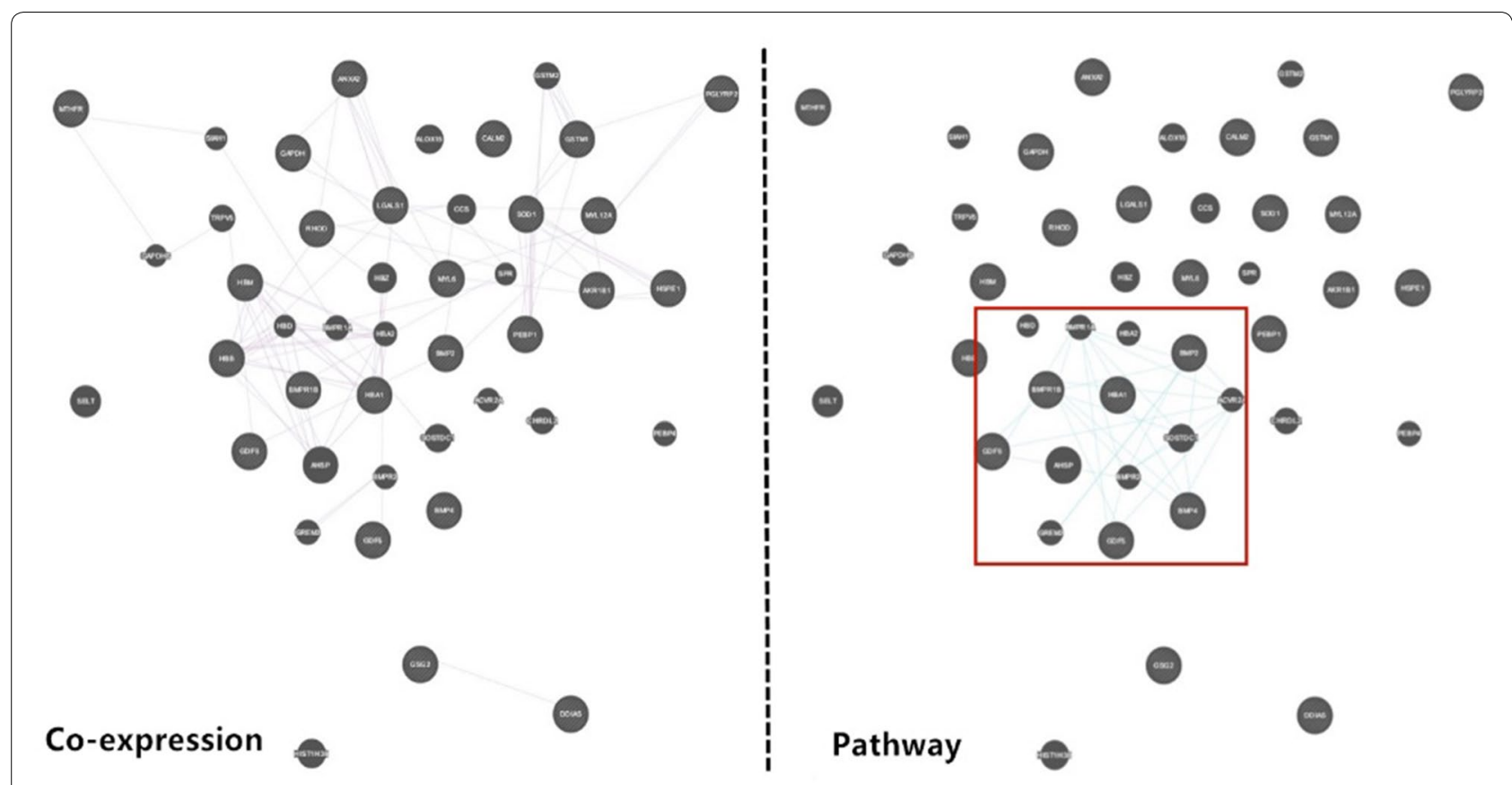

Fig. 12 Protein-protein interaction networks of BMPR-1B in ewe's ovary extracts based on GeneMANIA software of Co-expression and pathway

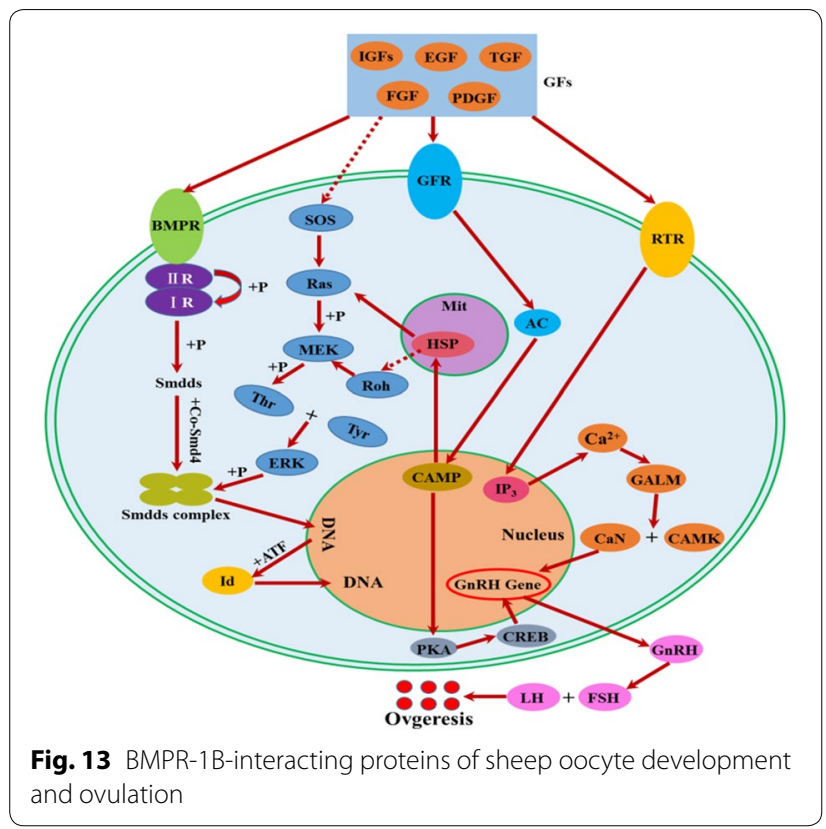

of LH, the phosphorylated HSP 10 can close the gap junction between follicle and oocyte, which results in a decreased cAMP level in the oocyte. At the same time, calcium and calmodulin transfer the GnRH signal to the protein binding site of the tyrosine kinase receptor using the p38-MAPK pathway, which achieves the regulation of animal reproductive traits $[32,33]$. The results of Ling showed that HSP 10 was involved in the regulation of ovarian granulosa cell apoptosis, which might affect both the follicular and oocyte maturation. The expression of HSP 10 in stromal cells of PCOS patients was low, anti-apoptosis was weakened, and follicular development was suppressed. Furthermore, HSP 10 was highly expressed in theca cells, and the IGF-1/ TGF- $\beta$ pathway was activated, which caused hyperandrogenemia, and inhibited both follicle maturation and ovulation [34]. As a key molecule of the Erk-MAP kinase pathway, Rho family proteins played a bridging role in the intracellular signal transduction [35]. RhoD participated in the Erk-MAP kinase pathway, where it could activate the pathway to participate in cell differentiation, produce cytokines, and initiate cell apoptosis. When RhoD expression was high, the MAPK pathway was activated, the residue of Tyr and Thr was phosphorylated, the ErK pathway was activated, and the phosphorylation levels of c-fos and c-jun increased. At the same time, the Smad 1 and Smad 5 also showed increased expression; thus, the oocyte differentiation and ovulation were induced [36-38].

\section{Conclusions}

CoIP-MS identified 23 proteins that specifically interacted with BMPR-1B proteins within ewes' ovary extracts. These proteins were primarily related to developmental processes, multicellular organismal processes, and biological regulation. The signal pathway of target 
proteins (BMP2, BMP4, GDF5, GDF9, RhoD, and HSP 10) was constructed and bioinformatics prediction showed that BMPR-1B interacts with proteins, thus promoting ovulation in ewe ovaries. In summary, the presented results provide new insight into BMPR-1B PPIs and their biological functions for sheep litter size. Furthermore, this study builds a technical foundation for in vitro expression of sheep BMPR-1B. To further study the biological function and for increased specificity of diagnostic reagents, BMPR-1B should be developed as the major gene of sheep.

\begin{abstract}
Abbreviations
BMPR-1 B: Bone morphogenetic protein receptors 1B; Co-IP: Co-immunoprecipitation; PPIs: Protein-protein interactions; MS: Mass spectrometry; Erk: Eukaryotic; MAPK: Mitogen-activated protein kinase; FSH: Follicle-stimulating hormone; LH: Luteinizing hormone; PCR-RFLP: Cleaved amplification polymorphism sequence-tagged sites; SDS-PAGE: Sodium dodecyl sulfate- polyacrylamide gel electrophoresis; CPE: Cytopathic effect; GO: Gene ontology; KEGG: Kyoto Encyclopedia of Genes and Genomes; MALDI-TOF/TOF: Matrix assisted laser desorption ionization time of flight mass spectrometry; LC-MS: Liquid chromatograph mass spectrometer.
\end{abstract}

\section{Acknowledgements}

We thank Dr. Liping Zhang (College of Animal Science and Technology, Gansu Agricultural University, Lanzhou Gansu, 730070, China) for his assistance in the manuscript writing.

\section{Authors' contributions}

$J \sqcup J$ and JPJ carried out the animal experiments and data analysis, and drafted the manuscript. YL and LSG designed the study and revised the manuscript. ZY and JHB participated in the animal trial. HQL QC with data collection and analysis. All authors read and approved the final manuscript.

\section{Availability of data and materials}

The datasets used or analyzed during the current study are available from the corresponding author on reasonable request.

\section{Ethics approval and consent to participate}

All experiments were conducted in compliance with the Institutional Animal Care Guidelines of Qinghai University.

\section{Consent for publication}

Not applicable.

\section{Competing interests}

The authors declare that they have no competing interests.

\section{Author details \\ ${ }^{1}$ Key of Laboratory of Plateau Ecology and Agriculture, Qinghai University, 251\#, Ningda Road, Chengbei District, Xining, Qinghai 810016, China. ${ }^{2}$ College of Agriculture and Animal Husbandry, Qinghai University, 251\#, Ningda Road, Chengbei District, Xining, Qinghai 810016, China. ${ }^{3}$ College of Animal Science and Technology, Gansu Agricultural University, Lanzhou Gansu 730070, China.}

Received: 14 November 2018 Accepted: 8 May 2020

Published online: 29 May 2020

\section{References}

1. Zhang X, Li W, Wu Y, Peng X, Lou B, Wang L, Liu M. Disruption of the sheep BMPR-IB gene by CRISPR/Cas9 in in vitro-produced embryos. Theriogenology. 2017;91(163-172):e162. https://doi.org/10.1016/j.theriogeno logy.2016.10.025.
2. Tian XE, Sun HX, Wang YJ. Genetic polymorphism of BMPR-IB gene and effect on litter size in three sheep breeds. J Northwest A F Univ. 2009;37(11):31-6. https://doi.org/10.13207/j.cnki.jnwafu.2009.11.031.

3. Yao YL, Reheman A, Xu YF. miR-125b contributes to ovarian granulosa cell apoptosis through targeting BMPR1B, a Major Gene for Sheep prolificacy. Reprod Sci. 2018;11:1933719118770544. https://doi.org/10.1177/19337 19118770544.

4. Ye L, Jiang WG. Bone morphogenetic proteins in tumour associated angiogenesis and implication in cancer therapies. Cancer Lett. 2016;380(2):586-97. https://doi.org/10.1016/j.canlet.2015.10.036.

5. Tseng JC, Chen HF, Wu KJ. A twist tale of cancer metastasis and tumor angiogenesis. Histol Histopathol. 2015;30(11):1283-94. https://doi. org/10.14670/HH-11-638.

6. Maskur M, Tapaul R, Kasip L. Genetic polymorphism of bone morphogenetic protein receptor 1B (BMPR-1B) gene and its association with litter size in Indonesian fat-tailed sheep. Afr J Biotech. 2016;15(25):1315-9. https://doi.org/10.5897/AJB2015.15093.

7. Abdoli R, Zamani P, Deljou A, Rezvan H. Association of BMPR-1B and GDF9 genes polymorphisms and secondary protein structure changes with reproduction traits in Mehraban ewes. Gene. 2013;524(2):296-303. https://doi.org/10.1016/j.gene.2013.03.133.

8. Wang J, Zhang LP, Ma Y, Jia JL, Li Z, Ding Q. Polymorphism of BMPR-IB Gene Exon7 in Five Populations. Chin Agric Sci Bull. 2013;29(29):46-51.

9. Jia JL, Zhang LP, Wu JP, Wang J, Ding Q. Establishment of the optimum two-dimensional electrophoresis system of ovine ovarian tissue. Genet Mol Res. 2014;13(3):6528-38. https://doi.org/10.4238/2014.August.26.3.

10. Miao XY, Luo QM, Zhao HJ, et al. Ovarian proteomic study reveals the possible molecular mechanism for hyperprolificacy of small tail han sheep. Sci Rep. 2016;27606:1-10. https://doi.org/10.1038/srep27606.

11. Vacca GM, Dhaouadi A, Rekik M, Carcangiu V, Pazzola M, Dettori ML. Prolificacy genotypes at BMPR 1B, BMP15 and GDF9 genes in North African sheep breeds. Small Ruminant Res. 2016;88(1):67-71. https://doi. org/10.1016/j.smallrumres.2009.11.005.

12. Carreira AC, Alves GG, Zambuzzi WF, Sogayar MC, Granjeiro JM. Bone morphogenetic proteins: structure, biological function and therapeutic applications. Arch Biochem Biophys. 2014;561(6):64-73. https://doi. org/10.1016/j.abb.2014.07.011.

13. Al-Samerria S. The role of bone morphogenetic proteins (BMPs) in ovarian function. Curtin University. 2016.

14. Jia JL. Screening and Analysis for Differential Expressed Proteins in Ewes Ovary Tissue of Different Lambing Performance. Gansu Agricultural University. 2015.

15. Miao X, Qin QL. Genome-wide transcriptome analysis of mRNAs and microRNAs in Dorset and Small Tail Han sheep to explore the regulation of fecundity. Mol Cell Endocrinol. 2015;402:32-42. https://doi. org/10.1016/j.mce.2014.12.023.

16. Cao JY, Xu YP, Cai XZ. TMT-based quantitative proteomics analyses reveal novel defense mechanisms of brassica napus, against the devastating necrotrophic pathogen sclerotinia sclerotiorum. J Proteomics. 2016;143:265-77. https://doi.org/10.1016/j.jprot.2016.03.006.

17. Li Y, Mahlon C, An JY. Immunoprecipitation and mass spectrometry defines an extensive RBM45 protein-protein interaction network. Brain Res. 2016;1647:79-93. https://doi.org/10.1016/.brainres.2016.02.047.

18. Wu C, Zong X, Zhao Z, et al. Genetic polymorphism analysis of BMP15 and GDF9 genes in six sheep breeds. China Anim Husbandry Vet Med. 2018;8:2236-46. https://doi.org/10.16431/j.cnki.1671-7236.2018.08.024.

19. Liu G, Zhang C, Wang G, Ji Z, Liu Z, Chao T, Zhang S, Wang J. Molecular cloning, characterization and tissue specificity of the expression of the ovine CSRP2 and CSRP3 genes from Small-tail Han sheep (Ovis aries). Gene. 2016;580(1):47-57. https://doi.org/10.1016/.gene.2016.01.021.

20. Springer A, Kratochwill K, Bergmeister H, Csaicsich D, Huber J, Bilban M, Mayer B, Mühlberger I, Amann G, Horcher E. A combined transcriptome and bioinformatics approach to unilateral ureteral obstructive uropathy in the fetal sheep model. J Urol. 2012;187(2):751-6. https://doi. org/10.1016/j.juro.2011.09.148.

21. Crispo M, Vilariño M, Santos-Neto $P C D$, Núñez-Olivera R, Cuadro F, Barrera N, Mulet AP, Nguyen TH, Anegón I, Menchaca A. Embryo development, fetal growth and postnatal phenotype of eGFP lambs generated by lentiviral transgenesis. Transgenic Res. 2015;24(1):31-41. https://doi. org/10.1007/s11248-014-9816-x. 
22. Maskur R, Arman C. Association of a novel single nucleotide polymorphism in growth hormone receptor gene with production traits in bali cattle. Italian J Anim Sci. 2014;13(4):3461-6. https://doi.org/10.4081/ ijas.2014.3461.

23. Pramod RK, Sharma SK, Kumar R, Rajan A. Genetics of ovulation rate in farm animals. Vet World. 2013;6(11):833-8. https://doi.org/10.14202/ vetworld.2013.833-838.

24. Ling J, Zhao K, Cui YG, Li Y, Wang X, Li M, Xue K, Ma X, Liu JY. Heat shock protein 10 regulated apoptosis of mouse ovarian granulosa cells. Gynecol Endocrinol. 2011;27(1):63-71. https://doi.org/10.3109/09513 590.2010.487594.

25. Sarmed Al-Samerria. The role of bone morphogenetic proteins (BMPS) in ovarian function. Philosophy Curtin University. 2016.

26. Soukup V, Kozmik Z. The Bmp signaling pathway regulates development of left-right asymmetry in amphioxus. Dev Biol. 2017;434(1):164-74. https ://doi.org/10.1016/j.ydbio.2017.12.004.

27. Antebi YE, Linton JM, Klumpe H, Bintu B, Gong M, Su C, Mccardell R, Elowitz MB. Combinatorial signal perception in the BMP pathway. Cell. 2017;170(6):1184-96. https://doi.org/10.1016/j.cell.2017.08.015.

28. Teixeira FR, Manfiolli AO, Vieira NA, Medeiros AC, Coelho PO, Santiago GD, Schechtman D, Gomes MD. Fbxo25 regulates mapk signaling pathway through inhibition of erk1/2 phosphorylation. Arch Biochem Biophys. 2017;621(1):38-45. https://doi.org/10.1016/j.abb.2017.04.003.

29. Wei LY, Zhang BW, Chen ZY, Xing G, Liao MH. Exploring local discriminative information from evolutionary profiles for cytokine-receptor interaction prediction. Neurocomputing. 2016;217(12):37-45. https://doi. org/10.1016/j.neucom.2016.02.078.

30. Zhang TT, Zhang GM, Jin YH, Guo YX, Wang Z, Fan YX, El-Samahy MA, Wang F. Energy restriction affect liver development in hu sheep ram lambs through hippo signaling pathway. Tissue Cell. 2017;49(5):603-11. https://doi.org/10.1016/j.tice.2017.08.004.

31. Xia B, Xu B, Sun Y, Xiao L, Pan J, Jin H, Tong P. The effects of liuwei dihuang on canonical wnt/ $\beta$-catenin signaling pathway in osteoporosis. J Ethnopharmacol. 2014;153(1):133-41. https://doi.org/10.1016/j.jep.2014.01.040.
32. Du M, Chen W, Zhang W, Tian XK, Wang T, Wu J, Gu J, Zhang N, Lu ZW Qian LX, Fei Q, Wang Y, Peng F, He X, Yin L. TGF- $\beta$ regulates the ERK/MAPK pathway independent of the SMAD pathway by repressing miRNA-124 to increase MALAT1 expression in nasopharyngeal carcinoma. Biomed Pharmacother. 2018;99:688-96. https://doi.org/10.1016/j.biopha.2018.01.120.

33. Xiao Y, Ye J, Zhou Y, Huang J, Liu X, Huang B, Zhu L, Wu B, Zhang G, Cai Y. Baicalin inhibits pressure overload-induced cardiac fibrosis through regulating AMPKJTGF- $\beta /$ smads signaling pathway. Arch Biochem Biophys. 2018;640(15):37-46. https://doi.org/10.1016/j.abb.2018.01.006.

34. Yang X, Huo H, Xiu C, Song M, Han Y, Li Y, Zhu Y. Inhibition of osteoblast differentiation by aluminum trichloride exposure is associated with inhibition of BMP-2/smad pathway component expression. Food Chem Toxicol. 2016;97:120-6. https://doi.org/10.1016/j.fct.2016.09.004.

35. Huang Q, Liu X, Wu Y, Liao Y, Huang Y, Wei X, Ma M. P38 MAPK pathway mediates cognitive damage in pentylenetetrazole-induced epilepsy via apoptosis cascade. Epilepsy Res. 2017;133:89-92. https://doi. org/10.1016/j.eplepsyres.2017.04.012.

36. Patraca I, Martínez N, Busquets O, Martí A, Pedrós I, Beas-Zarate C, Marin M, Ettcheto M, Sureda F, Auladell C, Camins A. Anti-inflammatory role of leptin in glial cells through P38 MAPK pathway inhibition. Pharmacol Rep. 2017;69(3):409-18. https://doi.org/10.1016/j.pharep.2016.12.005.

37. Chen Y, Nowak I, Huang J, Keng PC, Sun H, Xu H, Wei G, Lee SO. Erk/ MAP kinase signaling pathway and neuroendocrine differentiation of non-small-cell lung cancer. J Thoracic Oncol. 2014;9(1):50-8. https://doi. org/10.1097/JTO.0000000000000034.

38. Yosra B, Mongia A, Mar R, Ridha O. Immune profiling of human prostate epithelial cells determined by expression of p38/TRAF-6/ERK MAP kinases pathways. Kaohsiung J Med Sci. 2017;34(3):125-33. https://doi. org/10.1016/j.kjms.2017.10.002.

\section{Publisher's Note}

Springer Nature remains neutral with regard to jurisdictional claims in published maps and institutional affiliations.
Ready to submit your research? Choose BMC and benefit from:

- fast, convenient online submission

- thorough peer review by experienced researchers in your field

- rapid publication on acceptance

- support for research data, including large and complex data types

- gold Open Access which fosters wider collaboration and increased citations

- maximum visibility for your research: over 100M website views per year

At BMC, research is always in progress.

Learn more biomedcentral.com/submissions 